\title{
Fate of polychlorinated biphenyls in a contaminated lake ecosystem: Combining equilibrium passive sampling of sediment and water with total concentration measurements of biota
}

Chemical equilibrium status of an aquatic ecosystem

Mäenpää, Kimmo; Leppänen, Matti T.; Figueiredo, Kaisa; Mayer, Philipp; Gilbert, Dorothea; Jahnke, Annika; Gil-Allué, Carmen; Akkanen, Jarkko; Nybom, Inna; Herve, Sirpa

\section{Published in:}

Environmental Toxicology and Chemistry

Link to article, DOI:

10.1002/etc.3099

Publication date:

2015

Document Version

Publisher's PDF, also known as Version of record

Link back to DTU Orbit

Citation $(A P A)$ :

Mäenpää, K., Leppänen, M. T., Figueiredo, K., Mayer, P., Gilbert, D., Jahnke, A., Gil-Allué, C., Akkanen, J., Nybom, I., \& Herve, S. (2015). Fate of polychlorinated biphenyls in a contaminated lake ecosystem: Combining equilibrium passive sampling of sediment and water with total concentration measurements of biota: Chemical equilibrium status of an aquatic ecosystem. Environmental Toxicology and Chemistry, 34(11), 2463-2474. https://doi.org/10.1002/etc.3099

\section{General rights}

Copyright and moral rights for the publications made accessible in the public portal are retained by the authors and/or other copyright owners and it is a condition of accessing publications that users recognise and abide by the legal requirements associated with these rights.

- Users may download and print one copy of any publication from the public portal for the purpose of private study or research.

- You may not further distribute the material or use it for any profit-making activity or commercial gain

- You may freely distribute the URL identifying the publication in the public portal 


\title{
FATE OF POLYCHLORINATED BIPHENYLS IN A CONTAMINATED LAKE ECOSYSTEM: COMBINING EQUILIBRIUM PASSIVE SAMPLING OF SEDIMENT AND WATER WITH TOTAL CONCENTRATION MEASUREMENTS OF BIOTA
}

\author{
Kimmo MäenpäÄ, $* \dagger$ Matti T. Leppänen, $\dagger \ddagger$ Kaisa Figueiredo $\nmid \dagger$ Philipp Mayer, $\S \|$ Dorothea Gilbert, $\dagger \S$ \\ annika Jahnke,\# Carmen Gil-Allué, †† Jarkko Akkanen, Inna Nybom, $†$ and Sirpa Herve $\ddagger$ \\ $\dagger$ Department of Biology, University of Eastern Finland, Joensuu, Finland \\ $\ddagger$ Laboratory Centre, Finnish Environment Institute, Jyväskylä, Finland \\ $\S$ Department of Environmental Science, Aarhus University, Roskilde, Denmark \\ ||Department of Environmental Engineering, Technical University of Denmark, Lyngby, Denmark \\ \#Department of Cell Toxicology, Helmholtz Centre for Environmental Research, Leipzig, Germany \\ ††Department of Environmental Toxicology, Eawag, Dübendorf, Switzerland
}

(Submitted 23 April 2015; Returned for Revision 19 May 2015; Accepted 2 June 2015)

\begin{abstract}
Equilibrium sampling devices can be applied to study and monitor the exposure and fate of hydrophobic organic chemicals on a thermodynamic basis. They can be used to determine freely dissolved concentrations and chemical activity ratios and to predict equilibrium partitioning concentrations of hydrophobic organic chemicals in biota lipids. The authors' aim was to assess the equilibrium status of polychlorinated biphenyls (PCBs) in a contaminated lake ecosystem and along its discharge course using equilibrium sampling devices for measurements in sediment and water and by also analyzing biota. The authors used equilibrium sampling devices (silicone rubber and polyethylene [PE]) to determine freely dissolved concentrations and chemical activities of PCBs in the water column and sediment porewater and calculated for both phases the corresponding equilibrium concentrations and chemical activities in model lipids. Overall, the studied ecosystem appeared to be in disequilibrium for the studied phases: sediment, water, and biota. Chemical activities of PCBs were higher in sediment than in water, which implies that the sediment functioned as a partitioning source of PCBs and that net diffusion occurred from the sediment to the water column. Measured lipid-normalized PCB concentrations in biota were generally below equilibrium lipid concentrations relative to the sediment $\left(C_{\mathrm{Lip}} \rightleftharpoons \mathrm{Sed}\right)$ or water $\left(C_{\mathrm{Lip}} \rightleftharpoons \mathrm{W}\right)$, indicating that PCB levels in the organisms were below the maximum partitioning levels. The present study shows the application versatility of equilibrium sampling devices in the field and facilitates a thermodynamic understanding of exposure and fate of PCBs in a contaminated lake and its discharge course. Environ Toxicol Chem 2015;34:2463-2474. (C) 2015 SETAC
\end{abstract}

Keywords: Passive sampling Lipid Bioavailability Ecosystem Equilibrium Chemical activity

\section{INTRODUCTION}

Environmental monitoring of pollutants by passive samplers (among them, equilibrium sampling devices) is strongly evolving and has recently found new applications within exposure assessment. The deployment of equilibrium sampling devices is useful because equilibrium concentrations in the samplers can be translated into freely dissolved concentrations $\left(C_{\text {free }}\right)$, which is a parameter that describes bioavailability [1-5]. Furthermore, the weight of evidence in the scientific literature proves that (equilibrium) passive sampling performs better than traditional methods for environmental monitoring of hydrophobic organic chemicals in terms of versatility and utility [6,7].

Various passive sampling devices have been applied in the laboratory and in the field to measure concentrations of hydrophobic organic chemicals in various matrices, such as soil, sediment, water, and biota tissue. Such devices include solid-phase microextraction (SPME) fibers and silicone-coated glass vials [2,8-10]. Moreover, low-density PE [11,12], polyoxymethylene devices [13-15], ethylene vinyl acetate films [16], and silicone microtubes [17] have been used for

All Supplemental Data may be found in the online version of this article.

* Address correspondence to kimmo.maenpaa@uef.fi.

Published online 6 June 2015 in Wiley Online Library

(wileyonlinelibrary.com).

DOI: $10.1002 /$ etc.3099 passive sampling. Furthermore, refinements such as thin polymer layers and in vivo sampling of biota have increased the applicability of passive samplers, and new methods have been developed especially for predicting equilibrium partitioning concentrations of hydrophobic organic chemicals in model lipids [2,17,18-23].

In a recent equilibrium sampling study [9], SPME was applied in the headspace above polychlorinated biphenyl (PCB)-contaminated sediment. When thermodynamic equilibrium between the polymer as sampling phase and sediment was achieved, equilibrium partitioning concentrations in the polymer $\left(\mathrm{C}_{\mathrm{Pol} \rightleftharpoons \mathrm{Sed}}\right)$ were measured. Subsequently, these concentrations had been translated into equilibrium partitioning concentrations in model lipid phase $\left(\mathrm{C}_{\mathrm{Lip}} \rightleftharpoons\right.$ Sed $)$ using external calibration standards in olive oil. This provides a lipid concentration estimate for a hypothetical lipid-sediment equilibrium. Estimated $\mathrm{C}_{\mathrm{Lip}} \rightleftharpoons$ Sed values were higher than actual measured lipid-normalized concentrations $\left(C_{\mathrm{Lip}, \mathrm{Bio}}\right)$ of native sediment-dwelling invertebrates [9], possibly because of metabolization of the chemicals and a higher sorptive capacity of storage lipids compared with membrane lipids [18,24]. An organism may be in disequilibrium with its environment for several reasons, including slow uptake kinetics of hydrophobic organic chemicals, biomagnification, or biotransformation. Disequilibrium of organochlorines between sediment and fish was also observed in studies in the Baltic Sea [2] and a 
freshwater lake [25,26]. The disequilibrium was apparent whether the evaluation relied on passive sampler-derived chemical activities or the concentrations normalized to fish lipid and sediment organic carbon. According to the authors, such disequilibrium may have arisen because of a slower response of the sediment compartment, relative to air and water, to declining PCB levels. Furthermore, another study found that bioaccumulation of polyaromatic hydrocarbons (PAHs) and PCBs in native mussels was determined by interactive effects of sediment and overlying water [25]. It was concluded that the influence of both phases should thus be taken into consideration to estimate bioaccumulation by benthic organisms. However, sedimentdwelling organisms might be exposed to rather stable concentrations within the sediment. Consequently, when estimating thermodynamic equilibrium concentrations in lipids in such an approach, the different partitioning phases (e.g., sediment and water) should be considered, as well as when addressing and predicting bioaccumulation in general.

The equilibrium status between an organism and its environment can be measured in controlled laboratory tests using multiple sampling times but is difficult to determine for biota from the field because the choice of the main exposure medium, uptake routes, and kinetics relies on assumptions and because the determined equilibrium status will remain hypothetical. Nevertheless, the approach of calibrating equilibrium concentrations in equilibrium sampling devices $\left(C_{\mathrm{Pol}} \rightleftharpoons\right.$ Sed and $C_{\mathrm{Pol}} \rightleftharpoons \mathrm{w}$ ) against equilibrium partitioning concentrations in lipids can facilitate equilibrium assessment because such estimated lipid concentrations can provide a thermodynamic reference for evaluating actual biota concentrations [9].

In the present study we applied equilibrium sampling devices in the field to derive thermodynamic equilibrium partitioning reference levels for PCBs in biota lipids. A comparison of $\mathrm{C}_{\mathrm{Lip}}$, Bio with $\mathrm{C}_{\mathrm{Lip}} \rightleftharpoons$ Sed allows us to distinguish 3 scenarios: 1) $\mathrm{C}_{\mathrm{Lip}, \mathrm{Bio}}$ $\approx \mathrm{C}_{\mathrm{Lip} \rightleftharpoons \mathrm{Sed}}$, which is the case if organisms are in equilibrium with the sediment and bioconcentration (passive diffusion of freely dissolved chemical) is dominated by partitioning of hydrophobic organic chemicals into lipids; 2) $\mathrm{C}_{\mathrm{Lip}, \mathrm{Bio}}>$ $\mathrm{C}_{\mathrm{Lip}} \rightleftharpoons$ Sed , which would indicate biomagnification or protein binding; 3) $\mathrm{C}_{\text {Lip,Bio }}<\mathrm{C}_{\mathrm{Lip} \rightleftharpoons \text { Sed }}$, which is the case when organisms are in the kinetic uptake phase, biotransformation dominates, or partitioning processes hamper equilibration. Several of these processes also can occur simultaneously.

The first aim of the present study was to estimate the equilibrium status of PCBs at different sites within a contaminated lake ecosystem, which included the following steps: 1) applying the silicone-coated glass jars as equilibrium sampling devices for sediment; 2) exploring 2 types of equilibrium sampling devices in water; 3) deriving $\mathrm{C}_{\mathrm{Lip}} \rightleftharpoons$ Sed and $\mathrm{C}_{\mathrm{Lip} \rightleftharpoons \mathrm{W}}$; 4) comparing $\mathrm{C}_{\mathrm{Lip} \rightleftharpoons \mathrm{Sed}}$ and $\mathrm{C}_{\mathrm{Lip}} \rightleftharpoons \mathrm{W}$ with $\mathrm{C}_{\mathrm{Lip}, \mathrm{Bio}}$ from exhaustive extraction; and 5) conducting uptake experiments with caged mussels and benthic worms. Furthermore, chemical activities and chemical activity ratios were calculated. The second aim was to investigate the discharge of PCBs downstream of the historically contaminated lake sediment for assessing the distribution of the contamination.

\section{MATERIALS AND METHODS}

\section{Chemicals}

Standards for PCB congeners 18, 28, 31, 44, 49, 52, 101, 105, $110,118,138,149,151,153,156$, and 180 (International Union of Pure and Applied Chemistry enumeration) were purchased from Labor Dr. Ehrenstorfer-Schäfers. We used PCB 30 as an internal standard. The solvents (analytical grade) were purchased from Lab-Scan Analytical Sciences, and granular anhydrous sodium sulfate (J.T. Baker) was dried prior to use at $450{ }^{\circ} \mathrm{C}$ for $2 \mathrm{~h}$.

\section{The sampling sites}

The study area, the main lake basin of Lake Kernaalanjärvi $\left(60^{\circ} 52^{\prime} 25^{\prime \prime} \mathrm{N}, 24^{\circ} 36^{\prime} 30^{\prime \prime} \mathrm{E}\right)$ in southern Finland, was contaminated by discharges of PCB oils from a paper mill between 1956 and 1984 [27]. The surface area of Lake Kernaalanjärvi (site 2) is approximately $4.4 \mathrm{~km}^{2}$, and that of the contaminated sections of River Tervajoki (site 1) is approximately $0.5 \mathrm{~km}^{2}$. Sampling was performed at 6 different field sites (Figure 1): sites 1 to 5 are the sampling stations downstream $(\sim 3 \mathrm{~km}$, $5 \mathrm{~km}, 10 \mathrm{~km}, 13 \mathrm{~km}$, and $22 \mathrm{~km}$ ) from the historical source of PCBs, and site 6 is a reference site, approximately $1 \mathrm{~km}$ upstream from the contaminated area. Bioavailability and trophic transfer of PCBs in the study area $[9,28]$ as well as PCB toxicity [29] have been studied previously. The findings of the recent study [28] led the Finnish authorities to recommend consumption limits on several fish species from the lake [30].

\section{Ex situ equilibrium passive sampling of sediment}

Surface sediment samples $(\sim 5-7 \mathrm{~cm}$ depth) were collected from each sampling site on 5 May 2010 using an Ekman dredge and stored at $4{ }^{\circ} \mathrm{C}$ in darkness until analysis. At the southern end of Lake Kernaalanjärvi (site 2), samples were taken from 5 sampling locations and pooled to account for spatial differences in the PCB contents of the lake sediment. At all the downstream sampling sites, sediment was collected from a single sampling spot. An equal amount of sediment was collected from each location ( 30 L). Silicone-coated glass jars [8] were used for equilibrium passive sampling of PCBs from the sediment $[2,9]$. This sampling method had initially been developed for PAHs in soils [8] and was later modified for the equilibrium sampling of PCBs from sediment [9].

\section{In situ passive sampling of water}

The overlying water column was sampled with 2 different equilibrium sampling devices in 2010. A time series experiment with multiple sampling times was undertaken to assess the sampling kinetics and measure the equilibrium concentration of PCBs in the equilibrium sampling devices. Several PE sheets $(0.926 \mathrm{~g} / \mathrm{mL}$, thickness of $30 \mu \mathrm{m}$; Ab Rani Plast Oy) and silicone-coated fabric BiscaSil7W (Biscor) were cut in $5 \times 100 \mathrm{~cm}$ and $10 \times 30 \mathrm{~cm}$ pieces, respectively. BiscaSil7W (referred to as "Biscasil" hereafter) is a $90-\mu \mathrm{m}$-thick glass fiber fabric with a $60-\mu \mathrm{m}$ silicone coating on each side (i.e., total thickness of $210 \mu \mathrm{m}$ ). Before use, the PE sheets were precleaned according to Adams et al. [11], and Biscasil sheets were washed 3 times for $2 \mathrm{~h}$ each with excess ethylacetate under constant shaking. Solvents were then completely evaporated off the sheets in a fume hood, and the sheets were stored immersed in MilliQ water in glass jars until use.

For exposure at the field sampling sites, the sheets were secured into approximately $40 \times 25 \times 25-\mathrm{cm}$ metal cages using metal wire, and the cages were hung from buoys at approximately $1 \mathrm{~m}$ depth in the water column. The water column depth varied between $3 \mathrm{~m}$ and $5 \mathrm{~m}$ between the sites of water sampler deployment. Several cages were used to provide enough space for the sheets to be constantly exposed in the free water flow. A time series experiment with multiple sampling times was performed to measure the equilibrium 


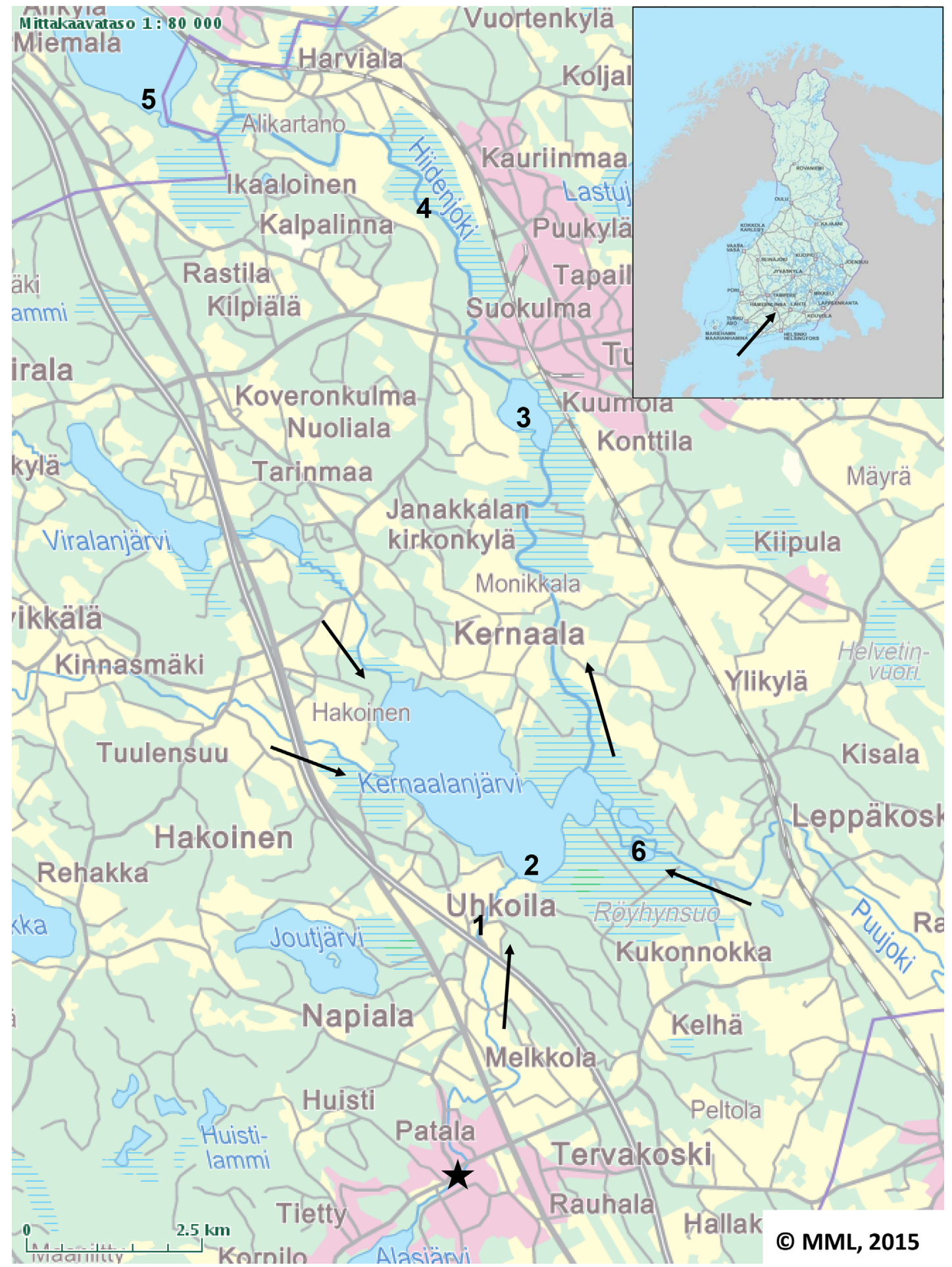

Figure 1. Map of the sampling area and the sampling sites (1-6). The historical source of polychlorinated biphenyl oils is indicated with the star, and the direction of water flow of each main river is shown with arrows. Site $1=$ River Tervajoki; site $2=$ Lake Kernaalanjärvi; site $3=$ Turenki; site $4=$ River Hiidenjoki; site $5=$ Lake Miemalanselkä; site $6=$ River Puujoki (reference site).

concentration of PCBs in the equilibrium sampling devices. Deployment of the samplers was started simultaneously with the water sampling on 5 May 2010, and samples were collected 4 times during the present study period: after $28 \mathrm{~d}$, $98 \mathrm{~d}, 147 \mathrm{~d}$, and $181 \mathrm{~d}$. At each sampling event, 3 to 6 replicate sheets of each sampling material were taken from each sampling site, and sheets were put in 200-mL glass jars, which were filled with water from the sampling site. The sheets were stored for approximately 2 mo to $5 \mathrm{mo}$ in $4{ }^{\circ} \mathrm{C}$ in darkness until analyzed.

In situ mussel exposure

Several mussels (Anodonta piscinalis) were collected from uncontaminated lake and incubated in an aquarium with clean water without feeding for $2 \mathrm{wk}$. After that, a composite sample of 7 mussels was collected for analysis of the background 
concentration of PCBs. The rest of the mussels were then exposed in the overlying water column of Lake Kernaalanjärvi (site 2) for 2 mo in June to July 2010. Mussels were placed in plastic traps, which were anchored at a depth of $1 \mathrm{~m}$ following the procedure described by Herve et al. [31,32]. Fifteen mussels were sampled after 1 mo and 2 mo of exposure. Both batches were divided into 2 subsamples ( 7 and 8 mussels each) and analyzed for PCBs and total lipids with the methods described by Herve et al. [33].

\section{Extraction of PCBs from equilibrium sampling devices}

Biofilms on the PE and Biscasil sheets were gently wiped with a soft brush and some cold tap water, and sheets were then blotted dry with lint-free tissue. The sheets were weighed and inserted into $100-\mathrm{mL}$ glass jars, and $40 \mathrm{~mL}$ of n-hexane and internal standard (PCB 30, $250 \mathrm{ng}$ ) was added. The jars were rolled constantly for $24 \mathrm{~h}$ to extract the PCBs from the polymers. The extract was collected, the extraction was repeated twice without addition of the internal standard, and finally the sheets were washed briefly with another $40 \mathrm{~mL}$ of n-hexane. As a keeper, $50 \mu \mathrm{L}$ of nonane was added into the combined solvent sample $(160 \mathrm{~mL})$, which was then evaporated to less than $5 \mathrm{~mL}$ in a rotary evaporator (Heidolph VB2000; Heidolph Instruments). The sample was further evaporated under a gentle nitrogen flow to approximately $2 \mathrm{~mL}$, and then $1 \mathrm{~mL}$ of concentrated sulfuric acid $\left(\mathrm{H}_{2} \mathrm{SO}_{4}\right)$ was added to remove impurities. The sample was then centrifuged $(665 \mathrm{~g}, 10 \mathrm{~min})$ and the solvent phase collected. The acid phase was briefly extracted again with $2 \mathrm{~mL}$ of $\mathrm{n}$-hexane and centrifuged, and the solvent phases were finally combined. One milliliter of acid was added to the combined solvent phase, the sample was centrifuged, and the acid was then carefully removed with a glass Pasteur Pipette. Next, the sample was evaporated under a nitrogen flow until near dryness, after which $300 \mu \mathrm{L}$ of isooctane and approximately $0.1 \mathrm{~g}$ of sodium sulfate $\left(\mathrm{Na}_{2} \mathrm{SO}_{4}\right)$ were added to remove possible water and acid left in the sample, which was then centrifuged $(665 \mathrm{~g}, 15 \mathrm{~min})$. Finally, the sample was transferred to a gas chromatography (GC) vial and stored at $-20{ }^{\circ} \mathrm{C}$ until GC-mass spectrometric (MS) analysis.

The procedure to extract PCBs from silicone-coated glass was done according to Mäenpää et al. [9] with some modifications. Briefly, sediment was poured off from the jar, and the jar was rinsed very briefly under running cold tap water. Immediately after, the silicone surface on the jar's inner wall was wiped with lint-free tissue, and the cap was cleaned and dried. Care was taken to avoid scratching the silicone surface. For extraction of PCBs from the silicone, $2 \mathrm{~mL}$ of $\mathrm{n}$-hexane and the internal standard (250 ng of PCB 30) were added and the jar was placed on a roller mixer $(10 \mathrm{rpm})$ for $60 \mathrm{~min}$. The extract was collected and the extraction repeated 3 times, and finally all extracts were pooled (i.e., $8 \mathrm{~mL}$ in total). Before the sample was evaporated to approximately $2 \mathrm{~mL}$ under a gentle stream of nitrogen, nonane $(0.5 \mathrm{~mL})$ was added. The sample was acidcleaned and further processed for analysis by GC-MS as described above.

\section{Characterization of whole sediment and mussels}

Sediment samples were analyzed in duplicate for PCBs with exhaustive extraction (Soxtec System HT, extraction unit model 1043 and 1046 service unit; Tecator), using n-hexane-acetone $(1: 1, \mathrm{v} / \mathrm{v})$ as an extraction solvent as described in Figueiredo et al. [28]. Wet sediment was dried prior to extraction using anhydrous sodium sulfate. Sediment samples from each site were also analyzed in triplicate for dry weight, total organic carbon (TOC), and black carbon as described in Grossman and Ghosh [34].

Native mussels were collected from Lake Kernaalanjärvi (site 2) in 2008 and included 17 specimens of Anodonta anatina and 14 specimens of Unio pictorum. The age of each individual was defined by the annual growth rings of the shell. The soft tissues of native mussels were homogenized (IKA ${ }^{\mathbb{B}}$ UltraTurrax dispenser; IKA-Werke) for PCB analysis by Soxhlet extraction as described in Figueiredo et al. [28]. The total lipid content in the mussel tissue was determined by applying the microscale method after Parrish [35] with the modification that 2-propanol-hexane $(2: 1, \mathrm{v} / \mathrm{v})$ was used as the extraction solvent. The method was tested for its accuracy by Figueiredo et al. [28] and showed good recovery $(97 \%)$ of lipids from standard reference material. The water content of the tissue samples was measured by drying tissue in an oven (Membert UE 400; Oy Tamro $\mathrm{Ab}$ ) at $105^{\circ} \mathrm{C}$ until constant weight and then subtracting the dry weight from the tissue's wet weight.

The long-term monitoring by Finnish authorities [36] of PCB concentrations in pike (Esox lucius) from Lake Kernaalanjärvi indicates that between 2002 and 2009 PCB levels stabilized (Supplemental Data, Figure S1).

\section{Lumbriculus variegatus bioaccumulation test}

Lumbriculus variegatus was exposed to sediment of Lake Kernaalanjärvi (site 2) in a standard bioaccumulation test [37] for $28 \mathrm{~d}$ to measure the steady-state concentrations of PCBs in a benthic species under laboratory conditions. The worms were sampled after $14 \mathrm{~d}$ and $28 \mathrm{~d}$ of exposure and analyzed for PCBs and total lipids as described in Figueiredo et al. [28]. The equilibrium partitioning level of PCBs in lipids relative to the sediment was derived by determining equilibrium partition concentrations in lipids $\left(C_{\mathrm{Lip} \rightleftharpoons \mathrm{Sed}}\right)$ using a headspace SPME method with external calibration standards in olive oil, as described in Mäenpää et al. [9].

\section{GC-MS analysis of PCBs and quality assurance}

The GC-MS analysis was performed as described in Figueiredo et al. [28]. Briefly, the analytes were separated with a Hewlett-Packard series 6890 GC system equipped with a nonpolar fused silica capillary column HP5-MS $(30 \mathrm{~m} \times 0.25$ mm i.d. $\times 0.25 \mu \mathrm{m}$ film thickness; Agilent Technologies). The injector was operated in splitless mode at a temperature of $225^{\circ} \mathrm{C}$. The oven temperature program was as follows: $90{ }^{\circ} \mathrm{C}(1$ min $), 150{ }^{\circ} \mathrm{C}\left(40^{\circ} \mathrm{C} / \mathrm{min}\right), 180^{\circ} \mathrm{C}\left(4^{\circ} \mathrm{C} / \mathrm{min}\right.$, held for $\left.3 \mathrm{~min}\right)$, and $270{ }^{\circ} \mathrm{C}\left(3.5^{\circ} \mathrm{C} / \mathrm{min}\right.$, held for $\left.8 \mathrm{~min}\right)$. Helium was used as a carrier gas $(0.7 \mathrm{~mL} / \mathrm{min})$. Analytes were identified by a mass selective detector (Hewlett-Packard) in electron ionization (70 eV) mode with single ion monitoring. The detector temperature was $280^{\circ} \mathrm{C}$.

Internal standard (PCB 30) and 5-point calibration curves were used for signal quantification. The accuracy of extraction and analysis was tested by analyzing the standard reference material SRM1946 (Lake Superior Fish Tissue; National Institute of Standards and Technology). The measured analyte concentrations in the reference material were within $75 \%$ to $125 \%$ of the assigned value (Supplemental Data, Table S1). Moreover, nonsample extracts were run as blanks with each sample batch (20 samples), and pure solvents were run after every 10 samples.

Detection limits were determined by analyzing 5 replicates of the lowest calibration standard $(0.05 \mathrm{ng} / \mu \mathrm{L})$. The standard deviation of the replicates was multiplied by the Student $t$ value at a significance level of $p=0.05$ (degrees of freedom $=4,1$ - 
sided distribution $t$ value $=2.132$ ) [38]. The instrumental detection limits were between $2.6 \mathrm{pg} / \mu \mathrm{L}$ and $11.4 \mathrm{pg} / \mu \mathrm{L}$ for the different analytes (Supplemental Data, Table S1).

Determination of $C_{\text {free }}, C_{\text {Lip }} \rightleftharpoons$ Matrix, and chemical activity

Concentrations of PCBs in the passive sampling polymers at equilibrium with either sediment porewater or the overlying water (respectively, $C_{\mathrm{Pol} \rightleftharpoons \mathrm{Sed}} C_{\mathrm{Pol} \rightleftharpoons \mathrm{w}}$ ) were converted to $C_{\text {free }}$ using analyte-specific polymer-water partition ratios $\left(K_{\mathrm{Pol} / \mathrm{W}}\right)$ :

$$
C_{\text {free }}=\frac{C_{\mathrm{Pol} \rightleftharpoons \mathrm{Matrix}}}{K_{\mathrm{Pol} / \mathrm{W}}}
$$

For the polymers $\mathrm{PE}$ and Silastic $\mathrm{A}, K_{\mathrm{PE} / \mathrm{w}}$ and $K_{\mathrm{Silastic}} \mathrm{A} / \mathrm{w}$ were taken from Smedes et al. [39]. The ratio $K_{\text {Biscasil/w }}$ was determined by applying Biscasil-Altesil partition ratios, $K_{\text {Biscasil/AlteSil }}$ (D. Gilbert, G. Witt, F. Smedes, and P. Mayer, Aarhus University, Roskilde, Denmark, unpublished data) as correction factor to Altesil-water partition ratios [39]:

$$
K_{\text {Biscasil } / \mathrm{W}}=K_{\text {Biscasil/Altesil }} \times K_{\text {Altesil } / \mathrm{W}}
$$

Measured concentrations in the sediment passive sampling polymer $\left(\mathrm{C}_{\mathrm{Pol}} \rightleftharpoons\right.$ Sed $)$ were converted to equilibrium partitioning concentrations in lipids $\left(\mathrm{C}_{\mathrm{Lip} \rightleftharpoons \mathrm{Sed}}\right)$ as described in Mäenpää et al. [9] by applying a polymer-specific lipid-polymer partitioning ratio $\left(\mathrm{K}_{\mathrm{Lip} / \mathrm{Pol}}\right)[40]$ :

$$
C_{\mathrm{Lip}} \rightleftharpoons \mathrm{Sed}=C_{\mathrm{Pol} \rightleftharpoons \mathrm{Sed}} \times K_{\mathrm{Lip} / \mathrm{Pol}}
$$

Silastic A silicone was used in the sediment passive sampler; therefore, $K_{\mathrm{Lip} / \text { SilasticA }}$ was inserted into Equation 3. Similarly, $C_{\mathrm{Lip}} \rightleftharpoons \mathrm{w}$ from water samplers (PE and Biscasil) was calculated via $K_{\mathrm{Lip} / \mathrm{PE}}$ and $K_{\mathrm{Lip} / \text { Biscasil. }}$.

$K_{\mathrm{Lip}, \mathrm{PE}}$ was taken from D. Gilbert et al. (unpublished data), and $K_{\mathrm{Lip}, \text { SilasticA }}$ and $K_{\mathrm{Lip}, \text { Biscasil }}$ were determined by applying Silastic A-SSP (SSP is a polydimethylsiloxane membrane from Specialty Silicone Products) and BiscasilSSP $\left(K_{\mathrm{Pol}, \mathrm{SSP}}\right)$ partitioning ratios (D. Gilbert et al., unpublished data), as correction factor to published lipid-SSP partition ratios [40].

$$
K_{\mathrm{Lip} / \text { Biscasil }}=\frac{K_{\mathrm{Lip} / \mathrm{SSP}}}{K_{\mathrm{Pol} / \mathrm{SSP}}}
$$

To calculate chemical activities of PCBs in the mussels, the concentration of model PCBs normalized to mussel total lipids $\left(C_{\mathrm{Lip}, \mathrm{Bio}}\right)$ was in a first step converted to the freely dissolved concentration, assuming partitioning solely into neutral lipids $\left(C_{\text {free,mussel }}\right)$, using $K_{\mathrm{Lip} / \mathrm{W}}$ (D. Gilbert et al., unpublished data) in the conversion:

$$
C_{\text {free, } \text { mussel }}=\frac{C_{\mathrm{Lip}, \mathrm{Bio}}}{K_{\mathrm{Lip} / \mathrm{W}}}
$$

Chemical activities $(a)$ in mussels, and likewise in sediment and water, were determined as

$$
a=\frac{C_{\text {free }}}{S_{\mathrm{L}}}
$$

where $S_{\mathrm{L}}$ is the subcooled liquid solubility calculated as described in van Noort [42] (Supplemental Data, Table S2).
Distribution of PCBs between $C_{\text {free }}$, dissolved organic carbon, and particulate organic carbon

The dissolved organic carbon (DOC) and particulate organic carbon (POC) contents in Lake Kernaalanjärvi (site 2) water were determined in a recent study [28]. The amount of PCBs in the different fractions, freely dissolved $\left(C_{\text {free }}\right)$ and bound to DOC $\left(C_{\mathrm{DOC}}\right)$ and POC $\left(C_{\mathrm{POC}}\right)$, were determined as follows:

$$
\begin{gathered}
C_{\mathrm{DOC}}=C_{\text {free }} \times\left([D O C] \times K_{\mathrm{DOC} / \mathrm{w}}\right) \\
C_{\mathrm{POC}}=C_{\text {free }} \times\left([P O C] \times K_{\mathrm{POC} / \mathrm{w}}\right)
\end{gathered}
$$

where $K_{\mathrm{DOC} / \mathrm{W}}$ is the DOC-water partition ratio from Burkhard [43] and $K_{\mathrm{POC} / \mathrm{W}}$ is the POC-water partition ratio from Mackay et al. [44]. Finally, the fraction of PCB free and bound forms was calculated as follows:

$$
\begin{gathered}
\%_{\text {free }}=\frac{C_{\text {free }}}{C_{\text {free }}+C_{\mathrm{DOC}}+C_{\mathrm{POC}}} \times 100 \\
\%_{\mathrm{DOC}}=\frac{C_{\mathrm{DOC}}}{C_{\text {free }}+C_{\mathrm{DOC}}+C_{\mathrm{POC}}} \times 100 \\
\%_{\mathrm{POC}}=\frac{C_{\mathrm{POC}}}{C_{\text {free }}+C_{\mathrm{DOC}}+C_{\mathrm{POC}}} \times 100
\end{gathered}
$$

\section{RESULTS AND DISCUSSION}

\section{Concentrations of $P C B$ in sediment}

Freely dissolved concentrations $\left(C_{\text {free }}\right)$ of $\Sigma$ PCBs in sediment porewater at equilibrium were highest at site 1 $(61 \mathrm{ng} / \mathrm{L})$, being $41 \%$ higher than at site 2 (Figure 2; Supplemental Data, Table S3). The concentrations were 94\% to $97 \%$ lower at downstream sampling sites. The $C_{\text {free }}$ indicates bioavailability, and hence, the highest PCB tissue residues in biota can be expected in the River Tervajoki area (site 1) for local species that do not migrate substantially, such as sedimentdwelling invertebrates. Correspondingly, tissue residues are anticipated to decrease downstream along with decreasing $C_{\text {free }}$ in sediment.

The total concentrations of $\Sigma$ PCBs in sediment, normalized to the sediment's TOC content (Supplemental Data, Table S4),

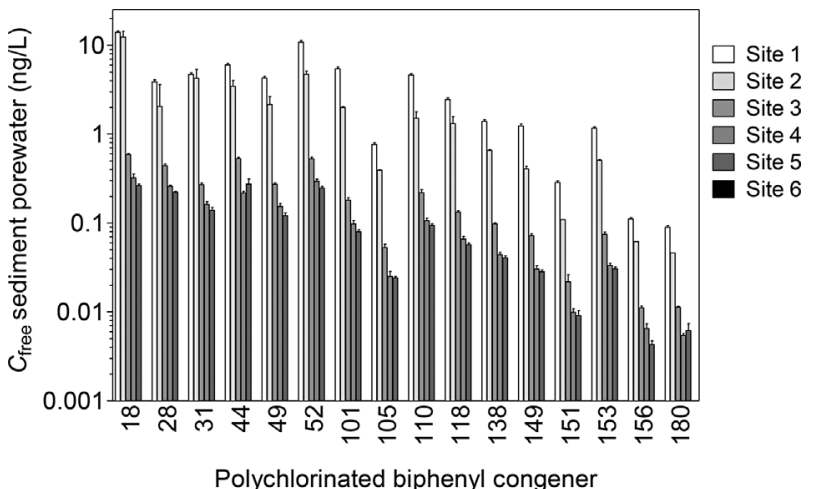

Figure 2. Freely dissolved concentrations of polychlorinated biphenyls (PCBs) in sediment porewater from the sampling sites, measured by equilibrium sampling using silicone-coated glass jars (mean \pm standard deviation, $n=9$ ). No PCBs were detected at the reference site (site 6). $C_{\text {free }}=$ freely dissolved concentration. 
were highest at site $2(138 \mathrm{mg} / \mathrm{kg}$ TOC), whereas the concentration for $\Sigma$ PCB at site 1 was $62 \%$ lower (Supplemental Data, Figure S2). Notably, the $C_{\text {free }}$ at equilibrium in sediment porewater was higher at site 1 compared with site 2 , whereas total concentration measurements showed the opposite. This may be attributed to the characteristics of hydrophobic organic chemical-binding carbonaceous materials in the sediment, which can vary between the sites. The $\Sigma$ PCB concentrations downstream of sampling site 2 were $93 \%$ to $97 \%$ lower, decreasing with distance.

\section{Concentrations of PCB in overlying water}

Passive samplers were deployed for up to $181 \mathrm{~d}$ using multiple sampling times to assess the sampling kinetics and to yield $C_{\text {free }}$ at equilibrium. Equilibrium between the samplers and the water phase was apparently reached after $147 \mathrm{~d}$ as no clear increasing trend was apparent in the determined ratio of the concentration in the polymer and polymer-water partition ratios $\left(C_{\mathrm{Pol}} / K_{\mathrm{Pol} / \mathrm{W}}\right)$ at $147 \mathrm{~d}$ and $181 \mathrm{~d}$ sampling times (Supplemental Data, Figure S3). Furthermore, the results from both sampler materials, PE and silicone-coated sheets (Biscasil), corroborate each other (Figure 3; Supplemental Data, Table S5 and Figure S3) despite the fact that diffusion rates of hydrophobic organic chemicals are reported to generally be higher in silicone than in PE [45].

Equilibration time depends on many factors that affect the rate at which chemicals partition from the matrix into the sampler, such as sampler material and thickness, diffusivities in polymers [45], water boundary layer thickness [46], and quality and quantity of chemical carriers (e.g., humic substances) in the water phase [47]. Correspondingly, equilibration times are expected to vary between the field sites. For example, Adams et al. [11] used 51- $\mu \mathrm{m}$-thick to $70-\mu \mathrm{m}$-thick PE sheets and observed equilibration times of a few days for PCB-52. Morgan and Lohmann [48] used the same PE material with $51 \mu \mathrm{m}$ thickness, and 15-d and 19-d exposure in PCB-contaminated surface water was enough to reach $90 \%$ of dissipation for PCB congeners 21 and 61, respectively, which were used as performance reference compounds in their study; this dissipation is assumed to reflect $90 \%$ of equilibrium $\left(t_{90 \%}\right)$ for the native chemicals taken up into the sampler.

There was good linear dependence of freely dissolved water concentrations on sediment porewater concentrations (Figure 4). Linear regression yielded a slope of 0.084 to 0.228 , which indicates that freely dissolved concentrations were consistently higher in the sediment than in the water at all sampling stations. This indicates that the sediment acts as a source of the chemicals to the overlying water phase.

Concentrations varied between both sampling sites and sampling times in the passive samplers deployed in the water. Initially, the increase in $C_{\mathrm{Pol}}$ can be attributed to the accumulation of PCBs in the polymer toward a chemical equilibrium between the water and the polymer (Supplemental Data, Figure S3). When close to equilibrium partitioning $\left(C_{\mathrm{Pol} \rightleftharpoons \mathrm{W}}\right)$ the concentration in the polymer can be expected to follow the $C_{\text {free }}$ of the surrounding water with a certain time lag, which may differ between the polymers and chemicals [45]. During the sampler deployment time in 2010, the water discharge had been approximately constant since the early weeks of June after an initial high-flow event (Supplemental Data, Figure S4). The initial high flow could have caused a dilution effect (slow diffusion into polymer) and consequently a pulse in $C_{\text {free }}$ after $100 \mathrm{~d}$ of deployment (Supplemental Data, Figure S3). After that, relatively constant concentrations in water were expected because significant dilution or concentration had consequently not occurred (Supplemental Data, Figure S4). Between the sampling sites, $C_{\text {free }}$ values of PCBs in the overlying water column were highest in Lake Kernaalanjärvi (site 2) throughout the sampling period from June to November compared with downstream sampling sites 3 to 6 . These differences can be attributed to a decline of $C_{\text {free }}$ downstream from Lake Kernaalanjärvi as a result of sedimentation of particle-bound PCBs and dilution with water from less contaminated areas of the ecosystem.

Biofouling may slow down the partitioning of compounds into a polymer, and surface-attaching biota may have different preferences for polymers, which may have a specific effect on the equilibration time of chemicals for different samplers. In the present study, biofouling was visible on both sampling materials and appeared slightly different between the sampling sites, and the appearance changed over time. Thus, the sampler surface was likely occupied by different biofouling agents between the seasons. Further studies should more intensely investigate the influence of biofouling on uptake and partitioning processes. A previous study showed that various complex matrices did not modify the sorptive properties of a silicone polymer [49], but biofouling was not addressed. We assume that biofouling had no effect on the sorptive properties of the samplers, whereas it could have affected the uptake rate of compounds into the polymers.
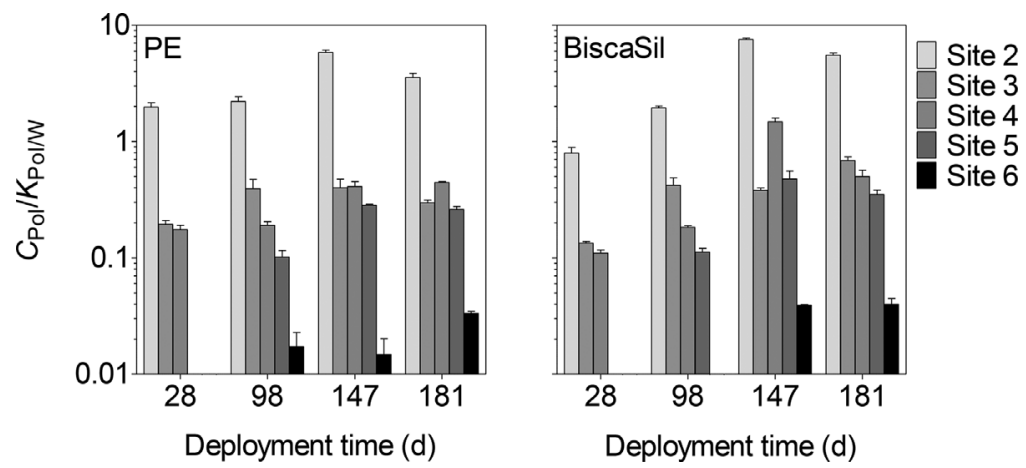

Figure 3. Comparison of the ratio $C_{\mathrm{Pol}} / K_{\mathrm{Pol} / \mathrm{w}}$ for polyethylene and silicone passive samplers in water at different sampling sites and times (mean \pm standard deviation; 28-147 d, $n=3 ; 181 \mathrm{~d}, n=4-6)$. There are no data from sampling site 1 and from sampling site 5 after 28 -d deployment time. Total polychlorinated biphenyls include congeners $28,31,44,49,52,101,105,110,118,138,149,151,153,156$, and $180 . C_{\mathrm{Pol}} / K_{\mathrm{Pol} / \mathrm{w}}=$ ratio of the concentration in the polymer and polymer-water partition ratios; $\mathrm{PE}=$ polyethylene. 

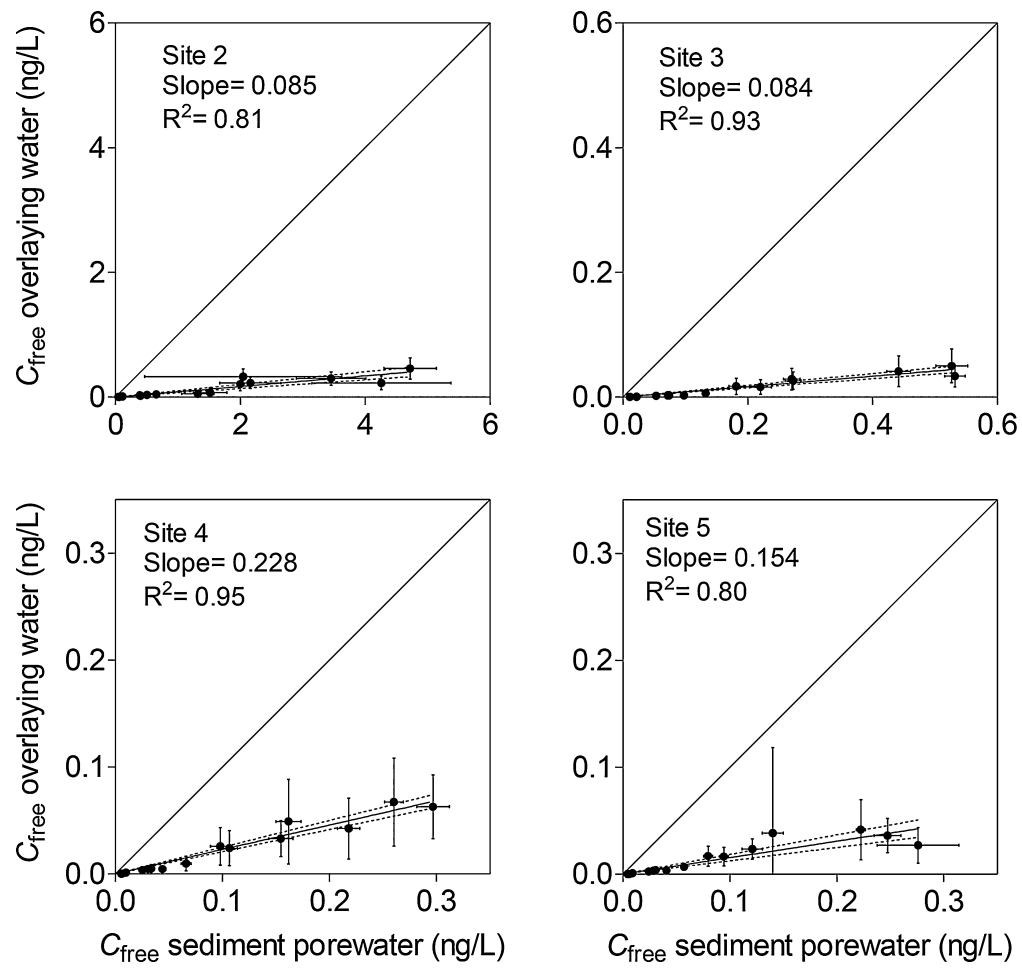

Figure 4. Freely dissolved concentrations of polychlorinated biphenyls in overlying water versus in sediment porewater (mean \pm standard deviation, overlying water $n=7-9$, porewater $n=9$ ) at the different sampling sites along the discharge course. Values for overlying water are calculated as mean ( \pm standard deviation) of the 2 last sampling times of both samplers because steady state was demonstrated after $147 \mathrm{~d}$. The data are fitted to linear regression (solid line), and $95 \%$ confidence limits are shown (dotted lines). $C_{\text {free }}=$ freely dissolved concentration.

Notably, we were also able to detect PCBs in the overlying water column at the reference site (site 6) where sediment total extraction and passive sampling of sediment failed in this regard. This was, however, not the result of a higher chemical activity of PCBs in the water phase but solely the result of the larger mass of sampler material (by more than 2 orders of magnitude) used for sampling of overlying water, which was sufficient to accumulate PCBs to levels above detection limits.

\section{Equilibrium partitioning concentrations in lipids}

Equilibrium partitioning concentrations in lipids versus actual concentrations in biota were explored to evaluate the equilibrium status of biota. The age of native mussels spanned several years (2-10 yr) without clear dependence between the age and PCB concentration (Supplemental Data, Figure S5), which reflects the long-term bioavailability of PCBs. Therefore, mussels of different ages were combined in the data analysis. The equilibration status of PCBs in mussel tissue plotted against the chemicals' log octanol-water partition coefficient [41] are shown in Figure 5. The estimated $C_{\mathrm{Lip}} \rightleftharpoons$ Sed was conservative compared with the measured $C_{\mathrm{Lip}, \mathrm{Bio}}$. In contrast, $C_{\mathrm{Lip} \rightleftharpoons \mathrm{w}}$ was closer to the measured $C_{\mathrm{Lip}, \mathrm{Bio}}$, which is the result of lower $C_{\text {free }}$ in the overlying water. For highly chlorinated congeners, bioaccumulation can be hindered because of kinetic restrictions of the uptake process [50]. In addition, biotransformation of PCBs by other mussel species has been observed [51]; hence, the result may indicate that mussels metabolize the less chlorinated PCBs. Both of these processes work against thermodynamic equilibrium and modify the tissue residue.

The Organisation for Economic Co-operation and Development's [37] standard test with $L$. variegatus showed that equilibrium was reached in $28 \mathrm{~d}$ for the 2 lightest congeners (PCB-8 and PCB-18), whereas equilibrium was not reached for the more hydrophobic congeners (Figure 6). In contrast to the mussel data, L. variegatus did not seem to be able to biotransform and eliminate even the least chlorinated congeners; thus, their body residues reached equilibrium. Body residues of PCBs in native Chironomus species analyzed in an earlier study [9] are in accordance with the present data. Unfortunately, no data exist for PCB 8 and PCB 18 for comparison. Concentrations of PCBs were lower in Chironomus sp. compared with $L$. variegatus, which may be a result of the generally more efficient metabolizing capability of Chironomus sp. [52-54]. In the case of the more highly chlorinated and more persistent congener PCB 180, Chironomus sp. had a higher body residue than L. variegatus. This is probably the result of lifelong exposure and, hence, close-toequilibrium partitioning PCB levels in the native Chironomus sp. collected from the lake sediment.

\section{Equilibrium status of the ecosystem}

The $C_{\text {free }}$ in overlying water was clearly lower than that in sediment porewater regardless of the sampling site (slope 0.084-0.228; Figure 4). This finding indicates that sediment acts as a source of PCBs to the overlying water phase, likely through desorption processes. In contrast, uncontaminated water flowing into the lake basin from other rivers has the opposite effect and lowers the chemical concentration in water by dilution. Thus, the overlying water column is constantly depleted by perfusion with uncontaminated water from upstream water sources. Lake Kernaalanjärvi, the main lake basin in the present study, has a short mean residence time of water of only $18 \mathrm{~d}$ [30]. In other words, 2 competing fluxes define the $C_{\text {free }}$ in the overlying water column-an input flux from sediment porewater with high $C_{\text {free }}$ and a depletive flux by the current of uncontaminated water from tributaries with low 

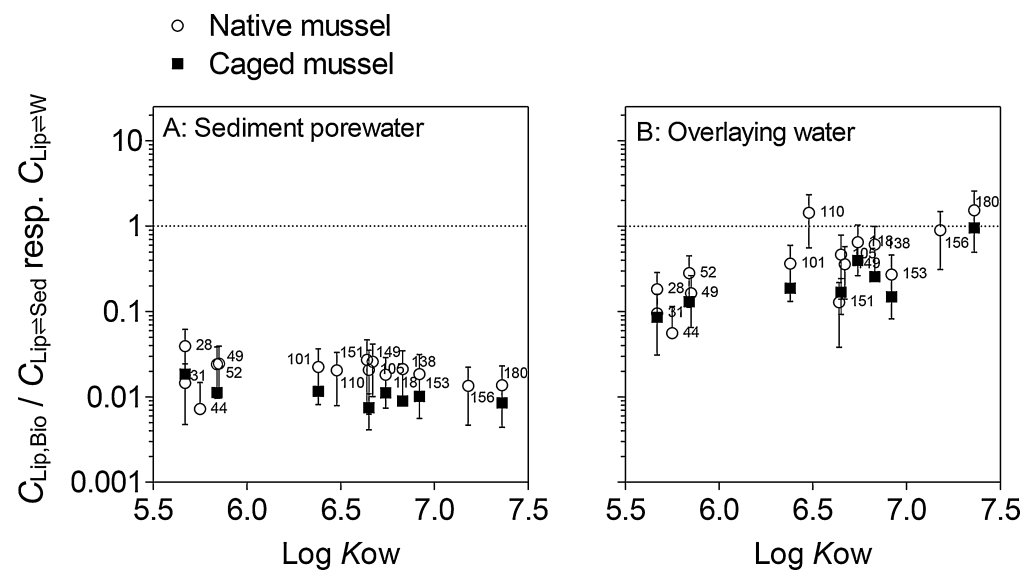

Figure 5. Estimation of chemical equilibrium of polychlorinated biphenyls (PCBs) in native mussels collected from Lake Kernaalanjärvi (site 2) and mussels caged in the lake overlying water column for 2 mo, plotted versus the chemicals' log octanol-water partition coefficient. The horizontal dotted line indicates equilibrium partitioning of PCBs between organism lipids and the sediment $(\mathbf{A})$ or water $(\mathbf{B})$. Lipid-normalized tissue concentrations $\left(C_{\mathrm{Lip}, \mathrm{Bio}}\right)$ of PCBs were

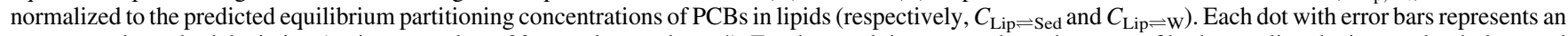
average and standard deviation (native mussel $n=30$, caged mussel $n=4$ ). For the overlying water phase the mean of both sampling devices, polyethylene and Biscasil, for the 2 last sampling events was calculated. $K_{\mathrm{OW}}=$ octanol-water partition coefficient.

$C_{\text {free. }}$ In addition, the entry of uncontaminated organic material (dissolved and particulate) from upstream may decrease freely dissolved PCB concentrations in the overlying water column through binding of PCBs. Consequently, $C_{\text {free }}$ in the overlying water may vary according to environmental factors such as flooding events caused by high precipitation. Indeed, a previous

- L. variegatus bioaccumulation test, exposure of $28 \mathrm{~d}$

○ L. variegatus bioaccumulation test, exposure of $14 \mathrm{~d}$

* Chironomus sp. [9]

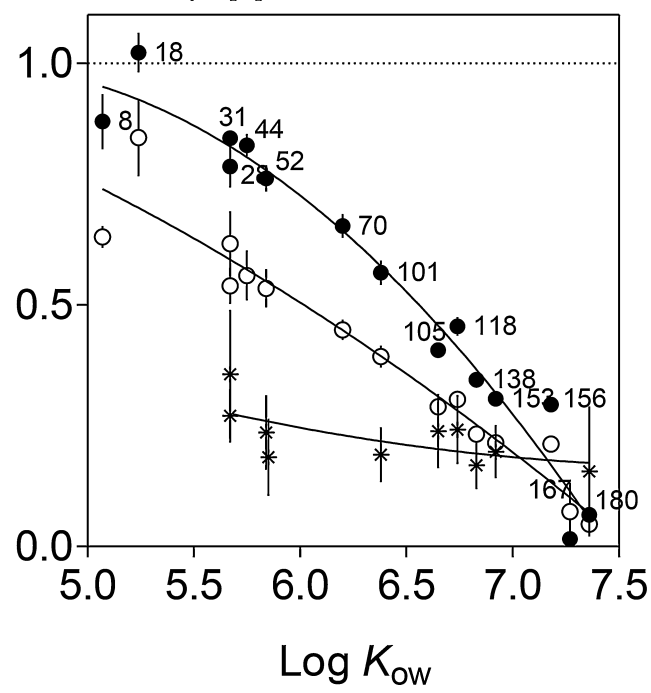

Figure 6. Estimation of chemical equilibrium for polychlorinated biphenyls (PCBs) in a standard bioaccumulation test with Lumbriculus variegatus [37] exposed to sediment of Lake Kernaalanjärvi (site 2) and with native Chironomus sp. collected from Lake Kernaalanjärvi [9]. Dots with error bars indicate the average and standard deviation of 3 replicate samples. The ratio of the lipid-normalized tissue concentration $\left(C_{\mathrm{Lip}, \mathrm{Bio}}\right)$ and the equilibrium partitioning concentrations in lipids $\left(C_{\mathrm{Lip}} \rightleftharpoons \mathrm{Sed}\right)$ are shown as a measure for the equilibration status. Horizontal line indicates equilibrium partitioning of PCBs between sediment and organisms. The data are fitted to a centered second order polynomial model (GraphPad Prism 5) for visualization. $\log K_{\mathrm{OW}}$ values are from Hawker and Connell [50]. $K_{\mathrm{OW}}=$ octanol-water partition coefficient. study found lowered body residues of total PCBs in caged mussels after high summer precipitation [31]. After all, the measured status of disequilibrium between the sediment porewater and overlying water may, in fact, present the steady-state situation in the studied dynamic ecosystem. Equilibrium sampling devices can therefore serve as an indicator for site-specific bioaccumulation.

When $C_{\mathrm{Lip}} \rightleftharpoons \mathrm{w}$ was used as the common equilibrium partitioning reference for the actual measured lipid-normalized PCB concentrations in mussels, the concentration ratios were close to or above 1 for native mussels (Figure 5B). The situation was the opposite when $C_{\mathrm{Lip}} \rightleftharpoons \mathrm{Sed}$ was used, where tissue residues were clearly below the estimated equilibrium partitioning reference level in lipid (i.e., $C_{\mathrm{Lip}, \mathrm{Bio}} / C_{\mathrm{Lip}} \rightleftharpoons \mathrm{Sed}<<1$ ). The food selection and feeding habits vary between mussel species, and possible food sources can include both suspended material from overlying water as well as sedimentary detritus [55-57]. Consequently, the mussels in the present study were potentially exposed to intermediate chemical concentrations between sediment porewater and overlying water, with food sources from overlying water probably dominating [58]. The mussels exposed for 2 mo in cages reached lower body residues (Supplemental Data, Table S6) compared with native mussels collected from the contaminated lake (Supplemental Data, Figure S6). This could be because of the short exposure period (i.e., equilibrium not being established) and/or the lack of exposure to sedimentary detritus for caged mussels. However, the caged mussels incubated for $1 \mathrm{mo}$ and 2 mo did not show any statistically significant differences $(p>0.33)$ in PCB body residues. This observation implies they were close to equilibrium or steady state already after 1 mo of exposure to overlying water. It may also indicate that sediment detritus plays a significant role in the uptake of hydrophobic organic chemicals in the native mussel species in the present study. In conclusion, both environmental exposure phases (sediment porewater and overlying water) that differed in their $C_{\text {free }}$ undoubtedly have a role in bioaccumulation. The estimates of $C_{\mathrm{Lip}} \rightleftharpoons$ Sed were conservative, however, which is in agreement with earlier findings $[2,9,25,26]$.

It is noteworthy that estimated equilibrium partitioning concentrations in lipid were $\left(C_{\mathrm{Lip}} \rightleftharpoons \mathrm{Sed}\right)$ determined for a model 
neutral storage lipid, which is only an idealized equilibrium partitioning reference phase because biota lipids have a more complex composition. It gives a good approximation for lipidrich biota such as eel, but it may be less accurate for lean biota in which other sorption phases such as polar lipids or proteins may be important for hydrophobic organic chemicals [18,24]. Currently, $C_{\mathrm{Lip}} \rightleftharpoons$ Sed reflects equilibrium partitioning concentrations in storage lipids, which show hardly any differences in their partitioning properties for hydrophobic organic chemicals $[40,59]$. In the present study, neutral lipids in mussels were assumed to be the only partitioning phase. Partitioning of bioaccumulative compounds between different sorbing phases of organisms has recently been investigated [18,60-62] to better define tissue-specific concentrations. These results showed that lipid normalization is a preferred transformation for the concentrations measured in biota because hydrophobic organic chemicals absorb predominantly in neutral lipids and less in polar lipids and proteins $[18,50,63]$. Therefore, the approach undoubtedly results in conservative estimates in this respect because a portion of the total lipids consists of polar lipids. However, partitioning into the protein phase may have an opposite effect because protein-associated PCBs are unintentionally mischaracterized when the whole-body PCB load is normalized to the concentrations in lipids. In lean organisms, such as mussels, the partitioning of hydrophobic organic chemicals to proteins may be substantial on a mass basis, and a small fraction of lipids would result in low total body residues [64]. Preincubation of caged mussels in clean water in the laboratory without feeding could have changed the proportion of lipid classes. Lower proportions of storage lipids compared with membrane lipids could consequently have contributed to the lowered body residue.

\section{Chemical activity}

Chemical activity $(a)$ is a valuable measure that can indicate the direction of partitioning processes of compounds between phases [4], and equilibrium passive sampling devices can be used as tools to measure such a thermodynamic parameters. Chemicals reach equilibrium when their energy levels are equal between phases as defined by the first law of thermodynamics. The law forms the basis of the equilibrium partitioning theory [65]. In a system of small spatial scale, partitioning processes toward phase equilibrium are relatively fast (local equilibrium). However, when a contaminated ecosystem is considered, several environmental and biological properties, such as fluctuation of contaminants and changes in lipid resources over time as well as biological processes such as biodegradation and biotransformation, operate against equilibrium. Hence, equilibrium partitioning levels in the phases of a complex system like an aquatic ecosystem cannot be expected to be reached [23,66,67], and thermodynamic equilibrium is instead used as a reference state to understand dynamic situations; $C_{\mathrm{Lip}} \rightleftharpoons \mathrm{Sed}$ is an example of that.

Another and more direct way of comparing the equilibration status between biota and sediment is to calculate activity ratios directly from measured concentrations in silicone equilibrated with biota and measured concentrations in silicone equilibrated with sediment, as suggested in a recent study [25]. In this case, in-tissue sampling was carried out until a thermodynamic equilibrium between the silicone and the tissue was established. This had been done for eel caught in Lake Miemalanselkä (site 5), approximately $15-\mathrm{km}$ downstream from Lake Kernaalanjärvi (site 2), in 2009 by Jahnke et al. [19]. The authors calculated eel-sediment activity ratios for 7 "indicator" PCBs, which ranged from 0.077 (PCB 180) to 0.188 (PCB 118). This gives additional evidence that PCB levels in aquatic species residing in this Finnish ecosystem are likely below equilibrium partitioning levels relative to the sediment. These results agree with what was observed in Lake Angen, a small lake in Sweden without known sources of pollutants other than the atmosphere, where PCBs had generally a lower activity in eels than in sediment (activity ratios of 0.048 for PCB 101 up to 0.295 for PCB 118) $[25,26]$. In the present study, the slope of the linear regression for the mussel-sediment activity ratio for different PCB congeners was 0.034 for the native mussels collected from site 2 (Supplemental Data, Figure S7B). These results agree with the previous studies and indicate that PCBs may not reach chemical equilibrium between biota and sediment.

Figure 7 shows estimated chemical activities $(a)$ of model PCBs in overlying water, sediment, and exposed mussels from Lake Kernaalanjärvi (site 2). Chemical activities in the overlying water were approximately $55 \%$ to $92 \%$ lower than those in sediment porewater, the difference increasing with increasing hydrophobicity of the congener. A similar trend of higher chemical activities in sediment compared with those in the overlying water has also been observed for PCBs and PAHs by Lohmann et al. [23]. The chemical activity ratios in each case indicate a diffusive flux of the chemicals that is directed from the sediment toward the overlying water column.

The bioavailability of PCB differed between sediment and overlying water and was indicated by differences in the PCB's chemical activity in these phases (Figure 7; Supplemental Data, Table S7). Hence, the habitat of an organisms within the ecosystem also determines the organism's exposure, which may be 1 of the factors determining the lower chemical activity in the caged mussels compared with the native mussels. Chemical activities of model PCB congeners in mussels clearly correlated better with the chemical activities in sediment porewater (Supplemental Data, Figure S7) than with the chemical activities in overlying water (Supplemental Data, Figure S8). In comparison, Lohmann et al. [23] derived chemical activities of PCBs and PAHs in native Mya arenaria and their surrounding environment, with the activities in $M$. arenaria being between the measured chemical activities in sediment and overlying water, which the researchers argued was the result of

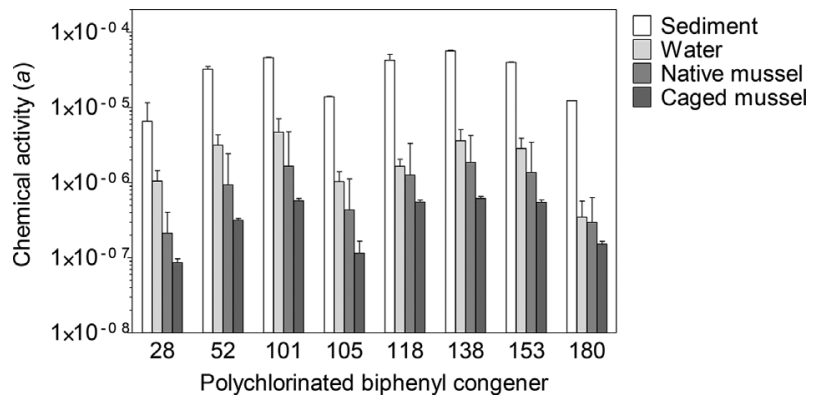

Figure 7. Chemical activity (a) of the model polychlorinated biphenyl congeners in different media of Lake Kernaalanjärvi (site 2). Chemical activities are shown for sediment porewater, overlying water, the native mussels, and the mussels caged for 2 mo in the water column. Chemical activities for the overlying water were calculated as the mean of measurements obtained from both the polyethylene and Biscasil passive samplers, for the 2 last sampling events for which chemical equilibrium was demonstrated. Each bar represents a mean and error bars, the standard deviation ( $n=9$ for porewater, $n=7-9$ for water, $n=30$ for native mussel, $n=4$ for caged mussel). 
exposure of the clams to both the overlying water column and the sediment.

\section{Distribution of PCBs in the study area}

The data of the total concentration in sediment, together with $C_{\text {free }}$ in sediment porewater and overlying water, give evidence that PCBs are leaking downstream in the studied ecosystem (Figures 2-4). Concentrations of PCB follow a logical dilution scheme along the discharge area downstream, and the PCB congener profile between the sampling sites (Figure 5) is similar, which together affirm a single source of contamination. Discharge of PCBs downstream and slightly decreasing PCB concentrations in incubated mussels had been measured during monitoring in 1984 to 1998 [32]. The present results indicate that discharge of PCBs downstream from the site where the PCB-releasing paper mill was located is still continuing.

The estimated binding of model PCB congeners to POC and DOC (Figure 8) suggests that POC and DOC can function as downstream carriers for PCBs, especially for the more highly chlorinated compounds, whereas less chlorinated congeners will likely discharge downstream in the freely dissolved form. Those PCBs that are bound to POC likely deposit to sediment along the discharge course, where conditions favor sedimentation, and can thus increase the total chemical concentration in the sediment (Figure 4). The magnitude of binding can vary as a result of changing conditions of leached organic material by precipitation and flood events, which subsequently can be expected to regulate freely dissolved concentrations and bioavailability in the overlying water.

Based on the concentrations measured, the Tervajoki River (site 1) still might slightly increase the bulk mass of PCBs in sediment of Lake Kernaalanjärvi (site 2) by discharge downstream. To model the mass balance of PCBs discharging downstream in more detail, further measurements of DOC and POC in the water column in different seasons would be needed because of their varying concentration over time.

Possible dredging as a mitigation action of the sediment in the most contaminated areas (site 1 and site 2 ) could be expected to especially increase the discharge of more highly chlorinated PCBs downstream because of resuspension of sediment during dredging and following an increase of suspended solids in the overlying water column. Alternatively, carbon amendments onsite would be a more suitable method to decrease the bioavailability of PCBs. For instance, amendment of activated

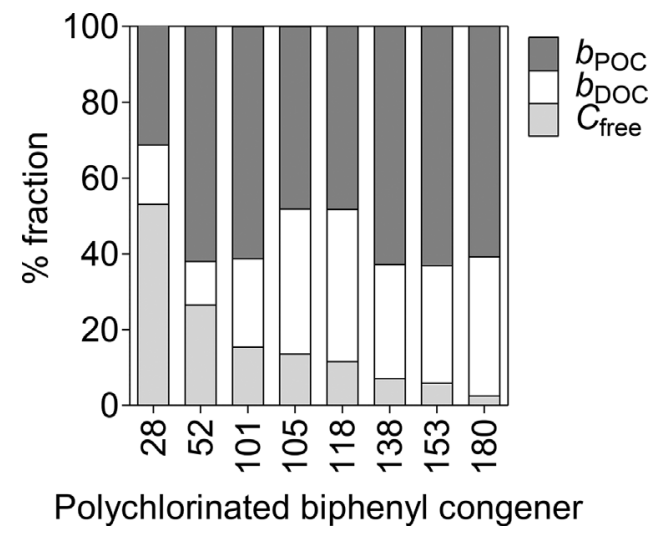

Figure 8. Estimated fractions of the model polychlorinated biphenyl congeners in the overlying water in Lake Kernaalanjärvi (site 2), distributed between freely dissolved concentrations $\left(C_{\text {free }}\right)$ and fractions bound to dissolved organic carbon $\left(b_{\mathrm{DOC}}\right)$ and particulate organic carbon $\left(b_{\mathrm{POC}}\right)$. carbon has been shown to decrease the bioavailability of PCBs in sediments [68].

\section{CONCLUSIONS}

In the present study the equilibrium status of an aquatic ecosystem, with historical pollution of PCBs in the sediment, was considered, taking different abiotic and biotic phases into consideration. The ecosystem appeared to be in disequilibrium, the sediment being a source phase and the overlying water and biota the receiving phases, being below the equilibrium level.

The estimated $\mathrm{C}_{\mathrm{Lip}} \rightleftharpoons$ Sed and $\mathrm{C}_{\mathrm{Lip} \rightleftharpoons \mathrm{W}}$ appeared conservative compared with the measured $\mathrm{C}_{\mathrm{Lip}, \mathrm{Bio}}$ in the present study, which is in accordance with previous findings. Several possible reasons exist for the concentrations measured in biota being below the predicted equilibrium partitioning concentrations relative to the sediment. High hydrophobicity and large molecular size can, for instance, limit uptake kinetics. The present study indicated that sediment-dwelling invertebrates as well as species having a long life span and hence exposure time, such as mussels, can be below the equilibrium partitioning concentrations. In particular, an overestimation is caused by using the $C_{\text {free }}$ of sediment porewater to predict the body residues of hydrophobic organic chemicals in the case of overlying water-filtering mussels. The equilibrium status of hydrophobic organic chemicals in ecosystems should be further investigated to gain evidence for other trophic levels. Such knowledge would help interpret standard laboratory equilibrium partitioning experiments for regulatory purposes designed to protect contaminated ecosystems.

The approach to estimate equilibrium partitioning concentrations of hydrophobic organic chemicals in lipids in general proved practical and can be recommended for use in further studies. Further development of the approach to take a more specific tissue composition of biota into account could improve its applicability and should be pursued.

The versatility of passive samplers was successfully demonstrated, and the methods used in the present study can be generally applied for monitoring in aquatic ecosystems for concentrations, status of the equilibrium, and discharge of contaminants along the discharge courses. Samplers could be efficient tools for implementation of the Water Framework Directive [69] of the European Union. The Common Implementation Strategy [70] for the Water Framework Directive was formulated to direct environmental monitoring of the priority substances in surface waters, which includes passive sampling as a complementary method. Furthermore, because passive sampling has been recognized as a useful tool to measure concentrations of hazardous substances in different environmental matrices, it is currently considered to be included in the Water Framework Directive [71]. Information obtained from the samplers could clearly complement standard exposure assessment for water and sediment.

\section{SUPPLEMENTAL DATA}

Tables S1-S7.

Figures S1-S8. (206 KB DOCX).

Acknowledgment-K. Mäenpää and M. Leppänen acknowledge the Academy of Finland for funding (projects 258120 and 123587, respective1y). P. Mayer acknowledges financial support from the US Strategic Environmental Research and Development Program (14 ER03-035/ER2431). The authors thank the staff of Lammi Biological Station of the University of Helsinki and Häme Centre for Economic Development, Transport and the Environment for help during the fieldwork. M. Noponen, 
J. Keronen, A. Romppanen, and S. Nikkonen are acknowledged for help with the laboratory work. A. Kostamo is acknowledged for reviewing the manuscript. The authors have no conflicts of interests to declare.

Data availability - Data can be accessed by contacting the corresponding author (kimmo.maenpaa@uef.fi).

\section{REFERENCES}

1. Mayer P, Parkerton TF, Adams RG, Cargill JC, Gan J, Gouin T, Gschwend PM, Hawthorne SB, Helm P, Witt G, You J, BI Escher. 2014. Passive sampling methods for contaminated sediments: Scientific rationale supporting use of freely dissolved concentrations. Integr Environ Assess Manag 10:197-209.

2. Jahnke A, Mayer P, McLachlan MS. 2012. Sensitive equilibrium sampling to study polychlorinated biphenyl disposition in Baltic Sea sediment. Environ Sci Technol 46:10114-10122.

3. Lohmann R, Booij K, Smedes F, Vrana B. 2012. Use of passive sampling devices for monitoring and compliance checking of POP concentrations in water. Environ Sci Pollut Res 19:1885-1895.

4. Reichenberg F, Mayer P. 2006. Two complementary sides of bioavailability: Accessibility and chemical activity of organic contaminants in sediments and soil. Environ Toxicol Chem 25:1239-1245.

5. Kraaij R, Mayer P, Busser FJM, Bolscher MV, Seinen W, Tolls J. 2003. Measured pore-water concentrations make equilibrium partitioning work: A data analysis. Environ Sci Technol 37:268-274.

6. Lydy MJ, Landrum PF, Oen A, Allinson M, Smedes F, Harwood A, Li H, Maruya K, Liu JF. 2014. Passive sampling methods for contaminated sediments: State of the science for organic contaminants. Integr Environ Assess Manag 10:167-178.

7. Lohmann R, Muir D. 2010. Global aquatic passive sampling (AQUAGAPS): Using passive samplers to monitor POPs in the waters of the world. Environ Sci Technol 44:860-864.

8. Reichenberg F, Smedes F, Jönsson J, Mayer P. 2008. Determining the chemical activity of hydrophobic organic compounds in soil using polymer coated vials. Chem Central J 2:8.

9. Mäenpää K, Leppänen MT, Reichenberg F, Figueiredo K, Mayer P. 2011. Equilibrium sampling of persistent and bioaccumulative compounds in soil and sediment: Comparison of two approaches to determine equilibrium partitioning concentrations in lipids. Environ Sci Technol 45:1041-1047.

10. Mayer P, Vaes WHJ, Wijnker F, Legierse KCHM, Kraaij R, Tolls J, Hermens JLM. 2000. Sensing dissolved sediment porewater concentrations of persistent and bioaccumulative pollutants using disposable solid-phase microextraction fibers. Environ Sci Technol 34:5177-5183.

11. Adams RG, Lohmann R, Fernandez LA, Macfarlane JK, Gschwend PM. 2007. Polyethylene devices: Passive samplers for measuring dissolved hydrophobic organic compounds in aquatic environments. Environ Sci Technol 41:1317-1323.

12. Booij K, Hofmans HE, Fischer CV, Van Weerlee EM. 2003. Temperature-dependent uptake rates of nonpolar organic compounds by semipermeable membrane devices and low-density polyethylene membranes. Environ Sci Technol 37:361-366.

13. Gschwend PM, MacFarlane JK, Reible DD, Lu X, Hawthorne SB, Nakles DV, Thompson T. 2011. Comparison of polymeric samplers for accurately assessing PCBs in pore waters. Environ Toxicol Chem 30:1288-1296.

14. Josefsson S, Karlsson OM, Malmaeus JM, Cornelissen G, Wiberg K. 2011. Structure-related distribution of PCDD/Fs, PCBs and HCB in a river-sea system. Chemosphere 83:85-94.

15. Jonker MTO, Koelmans AA. 2001. Polyoxymethylene solid phase extraction as a partitioning method for hydrophobic organic chemicals in sediment and soot. Environ Sci Technol 35:3742-3748.

16. Wilcockson JB, Gobas FAPC. 2001. Thin-film solid-phase extraction to measure fugacities of organic chemicals with low volatility in biological samples. Environ Sci Technol 35:1425-1431.

17. Mayer P, Toräng L, Glæsner N, Jönsson JA. 2009. Silicone membrane equilibrator: Measuring chemical activity of nonpolar chemicals with poly(dimethylsiloxane) microtubes immersed directly in tissue and lipids. Anal Chem 81:1536-1542.

18. Mäenpää K, Leppänen MT, Figueiredo K, Tigistu-Sahle F, Käkelä R. 2015. Sorptive capacity of membrane lipids, storage lipids, and proteins: A preliminary study of partitioning of organochlorines in lean fish from A PCB-contaminated freshwater lake. Arch Environ Contam Toxicol 68:193-203.
19. Jahnke A, Mayer P, Adolfsson-Erici M, McLachlan MS. 2011. Equilibrium sampling of environmental pollutants in fish: Comparison with lipid-normalized concentrations and homogenization effects on chemical activity. Environ Toxicol Chem 30:1515-1521.

20. Ouyang G, Oakes KD, Bragg L, Wang S, Liu H, Cui S, Servos MR, Dixon DG, Pawliszyn J. 2011. Sampling-rate calibration for rapid and nonlethal monitoring of organic contaminants in fish muscle by solidphase microextraction. Environ Sci Technol 45:7792-7798.

21. Yates K, Pollard P, Davies IM, Webster L, Moffat CF. 2011. Application of silicone rubber passive samplers to investigate the bioaccumulation of PAHs by Nereis virens from marine sediments. Environ Pollut 159:3351-3356.

22. Friedman CL, Burgess RM, Perron MM, Cantwell MG, Ho K, Lohmann R. 2009. Comparing polychaete and polyethylene uptake to assess sediment resuspension effects on PCB bioavailability. Environ Sci Technol 43:2865-2870.

23. Lohmann R, Burgess RM, Cantwell MG, Ryba SA, MacFarlane JK, Gschwend PM. 2004. Dependency of polychlorinated biphenyl and polycyclic aromatic hydrocarbon bioaccumulation in Mya arenaria on both water column and sediment bed chemical activities. Environ Toxicol Chem 23:2551-2562.

24. Ewald G, Larsson P. 1994. Partitioning of 14C-labelled 2,2',4,4'tetrachlorobiphenyl between water and fish lipids. Environ Toxicol Chem 13:1577-1580.

25. Jahnke A, Mayer P, McLachlan MS, Wickström H, MacLeod M. 2014 Silicone passive equilibrium samplers as "chemometers" in eels and sediments of a Swedish lake. Environ Sci Process Impacts 16:464-472.

26. Jahnke A, MacLeod M, Wickström H, Mayer P. 2014. Equilibrium sampling to determine the thermodynamic potential for bioaccumulation of persistent organic pollutants from sediment. Environ Sci Technol 48:11352-11359.

27. Koistinen J, Paasivirta J, Vuorinen P. 1989. Dioxins and other planar polychloroaromatic compounds in Baltic, Finnish and Arctic fish samples. Chemosphere 19:527-530.

28. Figueiredo K, Mäenpää K, Leppänen MT, Kiljunen M, Lyytikäinen M, Kukkonen JVK, Koponen H, Biasi C, Martikainen PJ. 2014. Trophic transfer of polychlorinated biphenyls (PCB) in boreal lake ecosystem: Testing of bioaccumulation models. Sci Total Environ 466467:690-698.

29. Koponen K, Huuskonen S, Ritola O, Venäläinen R, Tarhanen J, Lindström-Seppä P. 2003. Muscle chemical content and hepatic biotransformation in bream (Abramis brama) and asp (Aspius aspius) in a PCB-contaminated lake. Boreal Environ Res 8:203-213.

30. Paakkinen M, Piiroinen O. 2010. Vedenlaatu ja virkistyskelpoisuus Janakkalan kunnan alueella sijaitsevissa järvissä. Kokemäenjoen vesistön vesiensuojeluyhdistys ry. Kirje nro:824. Tampere, Finland. (in Finnish).

31. Herve S, Heinonen P, Paasivirta J. 2002. Survey of organochlorines in Finnish watercourses by caged mussel method. Resources, Conservation and Recycling 35:105-115.

32. Herve S, Paasivirta J, Heinonen P. 2001. Trends of organochlorine compounds in Finnish inland waters. Environ Sci Pollut Res 8:19-26.

33. Herve S, Heinonen P, Paukku R, Koistinen J, Paasivirta J. 1988. Mussel incubation method for monitoring organochlorine pollutants in watercourses. Four-year application in Finland. Chemosphere 17:1945-1961.

34. Grossman A, Ghosh U. 2009. Measurement of activated carbon and other black carbon in sediments. Chemosphere 75:469-475.

35. Parrish CC. 1999. Determination of total lipid, lipid classes, and fatty acids in aquatic samples. In Arts MT, Wainman BC, eds, Lipids in Freshwater Ecosystems. Springer-Verlag, New York, NY, USA, pp 4-20.

36. Kivinen S. 2010. Vanajaveden reitin yläosan kalojen PCB-pitoisuuden tarkkailu vuonna 2009. Kirje nro 346/SK. Kokemäenjoen vesistön vesiensuojeluyhdistys ry. Tampere, Finland. (In Finnish).

37. Organisation for Economic Co-operation and Development. 2008. Test No. 315: Bioaccumulation in sediment-dwelling benthic oligochaetes. OECD Guidelines for the Testing of Chemicals. Paris, France.

38. US Environmental Protection Agency. 1986. Guidelines establishing test procedures for the analysis of pollutants. Appendix B to Part 136Definition and procedure for the determination of the method detection limit, revision 1.11. Washington, DC. [cited 2014 December 1]. Available from: http://www.ecfr.gov/cgi-bin/text-idx? $\mathrm{SID}=852 \mathrm{de} 51 \mathrm{abb} 3 \mathrm{~d} 6195 \mathrm{ab} 78419 \mathrm{afd} 7164 \mathrm{~d} 3 \&$ node $=a p 40.23 .136 \_17$ b\&rgn=div9

39. Smedes F, Geertsma RW, Zande TVD, Booij K. 2009. Polymer-water partition coefficients of hydrophobic compounds for passive sampling: Application of cosolvent models for validation. Environ Sci Technol 43:7047-7054. 
40. Jahnke A, McLachlan MS, Mayer P. 2008. Equilibrium sampling: Partitioning of organochlorine compounds from lipids into polydimethylsiloxane. Chemosphere 73:1575-1581.

41. Hawker DW, Connell DW. 1988. Octanol-water partition coefficients of polychlorinated biphenyl congeners. Environ Sci Technol 22: 382-387.

42. van Noort PCM. 2009. Estimation of amorphous organic carbon/ water partition coefficients, subcooled liquid aqueous solubilities, and $\mathrm{n}$-octanol/water partition coefficients of nonpolar chlorinated aromatic compounds from chlorine fragment constants. Chemosphere 74:1024-1030.

43. Burkhard LP. 2000. Estimating dissolved organic carbon partition coefficients for nonionic organic chemicals. Environ Sci Technol 34:4663-4668.

44. Mackay D, Shiu WY, Ma K-C, Lee SC. 2006. Physical-Chemical Properties and Environmental Fate for Organic Chemicals. Taylor and Francis, Boca Raton, FL, USA.

45. Rusina TP, Smedes F, Klanova J. 2010. Diffusion coefficients of polychlorinated biphenyls and polycyclic aromatic hydrocarbons in polydimethylsiloxane and low-density polyethylene polymers. $J$ Appl Polymer Sci 116:1803-1810.

46. Mayer P, Tolls J, Hermens L, Mackay D. 2003. Equilibrium sampling devices. Environ Sci Technol 37:184A-191A.

47. Mayer P, Fernqvist MM, Christensen PS, Karlson U, Trapp S. 2007. Enhanced diffusion of polycyclic aromatic hydrocarbons in artificial and natural aqueous solutions. Environ Sci Technol 41: $6148-6155$

48. Morgan EJ, Lohmann R. 2008. Detecting air-water and surface-deep water gradients of PCBs using polyethylene passive samplers. Environ Sci Technol 42:7248-7253.

49. Jahnke A, Mayer P. 2010. Do complex matrices modify the sorptive properties of polydimethylsiloxane (PDMS) for non-polar organic chemicals? J Chromatogr A 1217:4765-4770.

50. Jonker MTO, van der Heijden S. 2007. Bioconcentration factor hydrophobicity cutoff: An artificial phenomenon reconstructed. Environ Sci Technol 41:7363-7369.

51. Livingstone DR, Nasci C, Sole M, DaRos L, O'Hara SCM, Peters LD, Fossato V, Wootton AN, Goldfarb PS. 1997. Apparent induction of a cytochrome P450 with immunochemical similarities to CYP1A in digestive gland of the common mussel (Mytilus galloprovincialis L) with exposure to 2,2',3,4,4',5'-hexachlorobiphenyl and Arochlor 1254. Aquat Toxicol 38:205-224.

52. Carrasco Navarro V, Leppänen MT, Kukkonen JVK, Godoy Olmos S. 2013. Trophic transfer of pyrene metabolites between aquatic invertebrates. Environ Pollut 173:61-67.

53. Verrengia Guerrero NR, Taylor MG, Davies NA, Lawrence MAM, Edwards PA, Simkiss K, Wider EA. 2002. Evidence of differences in the biotransformation of organic contaminants in three species of freshwater invertebrates. Environ Pollut 117:523-530.

54. Fisher SW, Chordas SW, Landrum PF. 1999. Lethal and sublethal body residues for PCB intoxication in the oligochaete, Lumbriculus variegatus. Aquat Toxicol 45:115-126.

55. Vieweg I, Hop H, Brey T, Huber S, Ambrose WG Jr, Locke VWL, Gabrielsen GW. 2012. Persistent organic pollutants in four bivalve species from Svalbard waters. Environ Pollut 161:134-142.
56. Wen ZR, Xie P, Xu J. 2009. Contributions of pelagic and benthic dietary sources to freshwater mussels: Evidence from stable carbon isotope analysis. J Freshw Ecol 24:425-430.

57. Raikow DF, Hamilton SK. 2001. Bivalve diets in a midwestern U.S. stream: A stable isotope enrichment study. Limnol Oceanogr 46:514-522.

58. Vuorio K, Tarvainen M, Sarvala J. 2007. Unionid mussels as stable isotope baseline indicators for long-lived secondary consumers in pelagic food web comparisons. Fundamental and Applied Limnology 169:237-245.

59. Geisler A, Endo S, Goss K-U. 2012. Partitioning of organic chemicals to storage lipids: Elucidating the dependence on fatty acid composition and temperature. Environ Sci Technol 46:9519-9524.

60. Endo S, Mewburn B, Escher BI. 2013. Liposome and protein-water partitioning of polybrominated diphenyl ethers (PBDEs). Chemosphere 90:505-511.

61. Escher BI, Cowan-Ellsberry CE, Dyer S, Embry MR, Erhardt S, Halder M, Kwon JH, Johanning K, Oosterwijk MTT, Rutishauser S, Segner H, Nichols J. 2011. Protein and lipid binding parameters in rainbow trout (Oncorhynchus mykiss) blood and liver fractions to extrapolate from an in vitro metabolic degradation assay to in vivo bioaccumulation potential of hydrophobic organic chemicals. Chem Res Toxicol 24:1134-1143.

62. van der Heijden SA, Jonker MTO. 2011. Intra- and interspecies variation in bioconcentration potential of polychlorinated biphenyls: Are all lipids equal? Environ Sci Technol 45:10408-10414.

63. van Wezel AP, Opperhuizen A. 1994. Thermodynamics of partitioning of a series of chlorobenzenes to fish storage lipids, in comparison to partitioning to phospholipids. Chemosphere 31:3605-3615.

64. DeBruyn AMH, Gobas FAPC. 2007. The sorptive capacity of animal protein. Environ Toxicol Chem 26:1803-1808.

65. Di Toro DM, Zarba CS, Hansen DJ, Berry WJ, Swartz RC, Cowan CE, Pavlou SP, Allen HE, Thomas NA, Paquin PR. 1991. Technical basis for establishing sediment quality criteria for nonionic organic chemicals using equilibrium partitioning. Environ Toxicol Chem 10:1541-1583.

66. MacDonald R, Mackay D, Hickie B. 2002. Contaminant amplification in the environment. Environ Sci Technol 36:456A-462A.

67. Tracey GA, Hansen DJ. 1996. Use of biota-sediment accumulation factors to assess similarity of nonionic organic chemical exposure to benthically-coupled organisms of differing trophic mode. Arch Environ Contam Toxicol 30:467-475.

68. Oen AMP, Janssen EML, Cornelissen G, Breedveld GD, Eek E, Luthy RG. 2011. In situ measurement of PCB pore water concentration profiles in activated carbon-amended sediment using passive samplers. Environ Sci Technol 45:4053-4059.

69. European Communities. 2000. Water Framework Directive 2000. Integrated river basis management in Europe. Directive 2000/60/EC. Brussels, Belgium.

70. European Communities. 2009. Common implementation strategy for the Water Framework Directive (2000/60/EC). Technical Report 2009025. Guidance Document no. 19. Guidance on surface water chemical monitoring under the water framework directive. Brussels, Belgium.

71. European Communities. 2011. Common implementation strategy for the Water Framework Directive (2000/60/EC). Technical Report 2011055. Guidance Document no. 27. Technical guidance for deriving environmental quality standards. Brussels, Belgium. 